\title{
On Webbed Monsters, Revolutionary Activists and Plutonium Glow: Eco-Crisis in Diane di Prima and Anne Waldman
}

\author{
Estíbaliz Encarnación-Pinedo
}

Citation: Encarnación-Pinedo, Estíbaliz. 2021. On Webbed Monsters, Revolutionary Activists and Plutonium Glow: Eco-Crisis in Diane di Prima and Anne Waldman. Humanities 10: 4. https://doi.org/ 10.3390/h10010004

Received: 12 November 2020 Accepted: 21 December 2020 Published: 28 December 2020

Publisher's Note: MDPI stays neutral with regard to jurisdictional claims in published maps and institutional affiliations.

Copyright: () 2020 by the author. Licensee MDPI, Basel, Switzerland. This article is an open access article distributed under the terms and conditions of the Creative Commons Attribution (CC BY) license (https: / creativecommons.org/ licenses/by/4.0/).
Department of Modern Languages, Polytechnic University of Cartagena, 30202 Cartagena, Spain; estibaliz.encarnacion@um.es

\begin{abstract}
Though green readings of Beat works are a relatively new phenomenon, the Beat aesthetic easily meets Lawrence Buell's criteria for ecocritical texts. Indeed, many writers associated with the Beat movement, such as Diane di Prima and Anne Waldman, often use their work to give shape to environmental concerns. This article studies the development of a green poetics in the work of both di Prima and Waldman. Focusing on works spanning four decades including Revolutionary Letters (1971), Loba (1998), Uh Oh Plutonium (1982) or The Iovis Trilogy (2011), to name a few, the article analyzes the poets' use of utopian and dystopian images through which they develop a poetics of eco-crisis that opposes the conformism and political tension of the American postwar and its aftermath.
\end{abstract}

Keywords: Beat women; eco-criticism; green reading; Diane di Prima; Anne Waldman

\section{Introduction}

When Ernest Callenbach published Ecotopia: The Notebooks and Reports of William Nelson (Callenbach 1975), a novel that helped introduce the ecological turn in utopian writing, many of the writers associated with the Beat generation had already expressed the urge to establish "greener" modes of interrelation between humankind and nature. While Callenbach's ecological utopia imagines a way of using technology as an ally, in STEPS (weiss 1958), ruth weiss's first published collection, the poet depicts a San Francisco whose closeness to nature is under the growing menace of a "webbed monster" (n.p.n.) that threatens with alienating a city that remains oblivious to what is happening: "you have invited the webbed monster to connect you he has a cement and steel-greedy eye" (n.p.p). About a decade later, Diane di Prima used the cool and detached beatnik argot to oppose the technological revolution with one based on environmental responsibility in Revolutionary Letter \# 34: "hey man, let's make a revolution, let's / turn off the power, turn on the/stars at night, put metal/back in the earth" (Di Prima [1971] 2007, p. 47). Just like di Prima, ecological concerns and green movement politics are present in the works of many other poets and writers associated with the so-called Beat movement, often times used to contest their own socio-political position, and to imagine a more harmonious way of living with nature.

An impressive array of Beat associates and aggregates, including Joanne Kyger, Ed Sanders, di Prima, Gary Snyder and Michael McClure featured in issue number 25 of the seminal interdisciplinary literary journal Io - edited by the ecological anthropologist Richard Grossinger. Entitled Ecology and Consciousness (Grossinger 1978), the volume collected texts on the verge of the 1980's that contained "eloquent examples of the literature of doom and darkness [ ... but also] literature against such premature darkness" (back cover). Much like the poets in this collection, Diane di Prima and Anne Waldman develop in their work an ecological awareness manifested in both images of ecological doom and ecological hope that often stem from their own environmental activism. Indeed, cemented by poets like Michael McClure-who recited his poem "For the Death of 100 Whales" at the legendary Six Gallery reading in 1955-the thematic centrality of nature and ecology 
informs not just the poetical output, but also the environmental activism practiced by many poets associated with both West Coast and East Coast literary groups such as Gary Snyder, Anne Waldman and Sister Mary Norbert Körte. This political engagement, which is present in the work of both di Prima and Waldman, has often been diluted-if not ignored-by the ecocritical discourse ${ }^{1}$ in part due to the aesthetic romantic naiveté, as well as the privileging of the white male perspective, of some of the encounters with nature portrayed in the work of these writers ${ }^{2}$. Nevertheless, an although green readings of Beat works are a relatively recent phenomenon ${ }^{3}$, the heterogenous and expansive Beat aesthetic does sit quite comfortably with Lawrence Buell's ecocritical criteria for nature writing $^{4}$ (Buell 1995), as it often emphasizes the presence of nature as an independent entity and stresses the interconnections between humankind and the environment. Drawing on such green interconnections and points of entrance, this article studies the prevalence of eco-concerned poetics in the work of Diane di Prima and Anne Waldman, two poets who, beyond sharing the inevitably synthetic and often externally imposed Beat label, participated actively in cultural and civil practices that shaped their political and ecological thinking. Though separated by a decade, both poets grew in artistic spheres dominated by men, which led them to adopt a fiercely autonomous stance that allowed them to rise above the rigidity of Cold War gender roles and collaborate with men, as di Prima puts it in her memoir, "beyond their one-upmanship" (Di Prima 2001, p.107). Furthermore, the poets' long-time friendship spans their participation in the Beat generation, forging their alliance through their shared interest in and study of Buddhism, as well as through their work at Naropa Institute and the Jack School of Disembodied Poetics (founded in 1974). Focusing mainly of di Prima's Revolutionary Letters (Di Prima [1971] 2007) and Loba (Di Prima 1998), and Waldman's video-poem "Uh Oh Plutonium" (Waldman 1982), the article analyzes how utopian and dystopian images, rather than succumbing to romanticized discourses, help the poets develop an aesthetic of eco-crisis that opposes the conformism and political tension of the American Cold War and its aftermath.

\section{The Revolutionary, the She-Wolf Goddess and the Green Look in Diane di Prima}

Diane di Prima's Revolutionary Letters, a collection she started publishing in the late 1960s but expanded periodically, shows a strong preoccupation with ecological issues. Using a discourse heavily embedded in utopian thinking, di Prima combines incendiary, hands-on poems where she calls for a revolution, with poems in which she offers glimpses of a utopian post-revolutionary world, as well as dystopian descriptions of her own society $^{5}$. Diluted through these different approaches, green concerns help the poet shape her revolution from the opening "April fool birthday poem for grandpa", a poem dedicated to her maternal grandfather and highly influencing figure, Domenico Mallozi ${ }^{6}$. Establishing the revolution as part of the anarchist lineage, this poem anticipates the ecological emphasis

1 In this article I use "ecocriticism" as well as "ecofeminism" as umbrella terms that include a range of theoretical and practical positions. See Buell's useful "Glossary of Selected Terms" (The Future of Environmental Criticism (Buell 2005)) for a description of related terms.

2 Discussing the work of writers such as Edward Abbey, Aldo Leopold or, among others, Gary Snyder, Ursula Heise notes in Sense of Place, Sense of Planet (Heise 2008) that "[w] hite male environmentalist writers between the 1950s and the 1970s often put the emphasis on the (usually male) individual's encounter with and physical immersion in the landscape, typically envisioned as wild rather than rural or urban." (29).

3 The most recent and comprehensive study of eco-consciousness in Beat writers-Burroughs is this case-is Chad Weidner's The Green Ghost: William Burroughs and the Ecocritical Mind (Weidner 2016). Before Weidner's analysis, most ecocritical studies had concentrated on Gary Snyder (see Murphy 2017; Tovey 2013; or Chen-Hsing Tsai 2012). Though not exactly from an ecocritical perspective, Jimmy Fazzino's World Beats: Beat Generation Writing and the Worlding of U.S. Literature (Fazzino 2016) does offer apt readings of the treatment of nature in works by Ginsberg and Burroughs.

4 Namely, 1. The nonhuman environment is present not merely as a framing device but as a presence that begins to suggest that human history is implicated in natural history; 2 . The human interest is not understood to be the only legitimate interest; 3 . Human accountability to the environment is part of the text's ethical orientation.; and 4. Some sense of the environment as a process rather than as a constant or a given is at least implicit in the text. (Buell 1995, pp. 7-8).

5 For a study of Diane di Prima's Revolutionary Letters as a critical utopia see Encarnación-Pinedo's “Utopia in Progress in di Prima's Revolutionary Letters" (Encarnación-Pinedo 2016).

6 Revolutionary Letters is dedicated to Bob Dylan and di Prima's grandfather. 
of the collection as the poet follows the teachings of her grandfather, who "pulled [her] hair when [she]/pulled the leaves off the trees so [she'd] now how it feels" (5). After a catalogue of anarchist and revolutionary figures such as Carlo Tresca, Sacco and Vanzetti, Trotsky or Jean Cocteau, di Prima dedicates the revolutionary effort in the collection to "the stars over the Bronx/that they may look on earth/and not be ashamed." (6) To attain this vision, the poet creates an image of humankind as one big organism, an approach influenced by the counterculture lifestyle di Prima took part of in the late 1960s-specially through Timothy Leary's experimental community at Millbrook (New York), as well as her collaboration with the radical community-action group the Diggers. Through this view, and in keeping with a de Tocquevillian reading of individualism as self-centered and egotistical, di Prima denounces in letter \#2 "the value of an individual life" as "a credo they taught us/to instill fear, and inaction" (8). Instead, and knowing full well that the changes called for by the revolution necessitate a collective effort, the poet asks revolutionaries-to-be to see themselves as one "Tribe/an organism, one flesh" (8) so that the actions started by one, can be ended by others if need be. Through the unifying and ordered action of this social organism - the "million earthworms/tunneling under this structure" (16) of letter \#7-the poems call for organized action to "reclaim the earth" (letter \#29, 42) in a movement that is described in marked ecological terms in subsequent letters:

the earth cries out for aid, our brothers and sisters set aside their childhoods, prepare

to fight, what choice have we but join them, in their hands

rests the survival of the very planet, the health

of the solar system [ ... ]

we must reclaim

the planet, re-occupy

this ground (letter \#35, 48)

Having established the green revolutionary positioning of the collection, the letters provide an array of answers to the different questioned raised by the previous poem; namely, why is earth crying? How can we ensure the survival of the planet? Or even should we reoccupy earth? All these questions are answered using the utopian/dystopian discourse through which the poet delineates the revolution. For instance, a set of letters offer a depiction of contemporary society in which nature is visibly endangered. In keeping with Buell's third criterion, which foregrounds "[h]uman accountability to the environment [being] part of the text's ethical orientation" (Buell 1995, p. 8), just as di Prima endows humankind with the power and even the obligation to "reclaim/the planet" (48), she also holds people accountable for the damage they inflict on nature. Letter \#16, as a case in point, opens up with a direct mea culpa that reads "we are eating up the planet" (28). This "we", in addition, is specifically located in the USA, a country which as the poet notes "has $5 \%$ of the world's people uses over $/ 50 \%$ of the world's goods" (28), and whose "garbage/holds matter for survival for uncounted/'underdeveloped' nations" (28). The anti-consumerist thinking behind these statements, as well as the direct correlation between consumerism and pollution, are further developed in the collection. In letter \#17, the poet warns the reader about the sacrifices people will need to make to ensure the continuity of the planet, arguing that "simply/the planet will not bear it" (29); and in letter \#31, subtitled "for The Poor People's Campaign" in reference to the movement organized in 1967 and 1968 by Martin Luther King, the poet goes beyond the campaign's basic claims to boldly denounce that "if what you want is jobs/for everyone, you are still the enemy" (31). In this poem, the legislations to secure basic needs such as access to employment and affordable housing sought by the campaign are watered down and ultimately discarded as it means, in the eyes of the revolutionary, sacrificing "the planet for a few years of some/science fiction utopia" (31). A big part of this science fiction utopia, notoriously built around economic prosperity and individual well-being, is refashioned in other letters through dystopian sketches that dismantle the alleged development of the poet's contemporary society. In these poems 
the poet refers to civilization as "the cancer" (letter \#32, 45) and laments how the city-as an entity- "consume[s] the air and water/for miles around it" (45). Although not exactly resorting to a pastoral mode, di Prima often launches an offence against a very particular type of city; a city that in letter \#60 pushes the poorest to the margin, and in letter \#54 provides women and men with a four-step recipe to become alchemical experiments:

$$
\begin{aligned}
& \text { eat mercury (in wheat \& fish) } \\
& \text { breathe sulphur fumes (everywhere) } \\
& \text { take plenty of (macrobiotic) salt } \\
& \text { \& cook the mixture in the heat } \\
& \text { of an atomic explosion (letter \#54,69) }
\end{aligned}
$$

The toxicity of contemporary life, and its connection to the industrialization and technologization of society, leads the poet to a reconceptualization of social life in greener, less scientific, terms. This envisioned world is often depicted through highly utopian and romantic lens, and more often than not, it includes a nostalgic look back at past times. In letter \#13, for instance, the poet calls for a collective wishful thinking to "put back the big trees/put back the buffalo [ ... ]/put fish in clean Great Lakes/desire that all surface water on the planet/be clean again" (24-25). In keeping with this vision of a simpler way of life closer to nature, the poet constructs post-revolutionary images where she presents alternatives to improve society; letter \#22, for instance, introduces the need to rethink education. Fueled by the realization that there is more to earth than human beings-the poet condemns lives lived "as if the planet were no more than a vehicle/for carrying our plastic constructs around the sun" (35) - the revolutionary delineates a new teaching system by which children are taught hands-on, almost out-in-the-woods survival skills, outside the "cement box called 'school"" (35). While in poems like this and others the poet uses a naive and ahistorical discourse to build her utopia - for instance, perpetuating the traditional and often essentialist view of women as nurturers closer to nature in letter \#44-many other letters in the collection explicitly situate the action in more tangible spheres. In letter \#9, as a case in point, opposition to the government translates in the direct targeting of "the head of Dow Chemical" (18), the American multinational chemical corporation which managed for over twenty years the Rocky Flats Plant (discussed later on) and manufactured napalm B compound during the Vietnam War. The centrality of the environmental discourse and the denunciation of specific consequences is also present in letter \#42, where the poet discredits the "'overpopulation' problem" (55) and denounces sterilization campaigns targeted at the less privileged such as women from India through the creation of the "sterilization bonus" (55) - a reference to one of the incentives put forward by the National Program for Family Planning.

Independently of the use of direct or indirect references, or the construction of the revolutionary discourse through vague or particular examples, di Prima keeps centering the crisis around the exploitation of nature. For instance, while in letter \#73-subtitled "Dream poem about Reagan \& Co" (100)—the poet forecasts the death of nature at the hands of politicians without pinpointing exactly how the crime is committed, in letter \#61, she enumerates and details the list of effects of the unrestrained exploitation of natural resources. Written at the onset of the oil crisis, the poem includes exploitative actions done "regardless of consequences" (78) such as offshore drilling, crude and shale oil extraction, or the creation of coal plants occupying Cheyenne territory. In letter \#80, written in the early 1990s, the exploitation of nature is paralleled to injustices against minority groups and the less privileged as the poet expands the definition of "terrorism":

Are you afraid to go out, to walk in yr city, yr suburb, yr ountryside?

To read, to speak yr own language, wear yr tribe's clothes?

Afraid of the thin-shelled birds w/ twisted necks

poisoned by nitrates, by selenium?

Afraid that the dawn will be silent, the forest grey? 
Is it terrorism to fill the Dnieper River w/ radiation?

or heat the ionosphere w / magnetism 'to see what will happen'? (116)

These rather dystopian poems are interwoven throughout the collection with utopian counterpoints of the revolutionary's reimagined society; an example being letter \#81, where the poet reinvents a road trip back home to portray a world where people live in harmonious union with one another and with nature- "On the way home/it will be easy to find pure water, organic tomatoes, friendly/conversation" (119). Although the revolutionary is also skeptical about the actual extent to which poetry can have an effect on the world ${ }^{7}$, the letters-even in their more utopian or naive version-do function as some kind of acts of environmental imagination which, as Lawrence Buell has noted, "whatever anyone thinks to the contrary, potentially register and energize four kinds of engagement with the world" (Buell 2001, p. 2). These engagements include different ways through which acts of the imagination such as novels or poems can indeed impact the physical world by stirring consciousness, changing attitudes or even calling people into action. The potential of these acts, as Buell writes, includes directing "thought towards alternatives futures" (Buell 2001, p. 2) and affecting "one's caring for the physical world: make it feel more or less precious or endangered or disposable" (Buell 2001, p. 2), two actions rather clearly intended by Revolutionary Letters. This reading is further supported by a historicized approach that takes into consideration di Prima's participation in the activist countercultural action carried out by the San Francisco Mime Group and the Diggers, two groups which fed into each other quite frequently. In this sense, the work of activist and Diggers co-founder Peter Berg helps situate di Prima's utopian vision within the framework of environmental activism. An environmental writer and bioregionalist, Berg complicates the naive reading in texts such as "Green City" (1986), where he describes the origins and development of the concept of a green city. Having been invited to speak at a rock concert in Golden Gate Park, Berg uses the opportunity to ask the audience to help him realize his "vision called green city" (in Glotfelty and Quesnel 2015, p. 86). Building his green city through audience participation-much like di Prima plots a collective revolution-Berg shows, in his own words, "how successful being naive can be" (in Glotfelty and Quesnel 2015, p. 85). This individual and communal envisioning, in addition, does not stop at the level of conception, but also leads to careful planning and designing aimed at taking action. This is the case of "A Metamorphosis for Cities: From Gray to Green" (first published in 1990), a text which reads like an agenda in outline form to make cities livable and that is also reminiscent of the revolutionary tips di Prima includes in her letters.

In this light, the Digger's catchphrase "do your thing", outlined by George Metesky ${ }^{8}$ in "The Ideology of Failure" (Metesky 1966) is mimicked or paralleled by di Prima's "ask for everything" (Letter \#19); a move that, more than a mere utopian stance, is intended to bring about a social revolution. As such, the evaluation of Diane di Prima's eco-concerns in Revolutionary Letters through utopian and dystopian sketches surpasses the romanticized or the pastoral modes in favor of a much more political position. This position, as the example of the Diggers shows, is impregnated by the age of revolt in which the poems were written, and which led to a number of activist groups such as the Student Nonviolent Coordinating Committee, the Environmental Justice Movement, or the Free Speech Movement as well as Timothy Leary's "Turn on, turn in, drop out" axiom.

Indeed, while the more utopian and essentialist poems in Revolutionary Letters may wrongly lead someone to think the poems shallow or even transitory rebellious blabberingRon Silliman has referred to the collection as "the silliest when it comes to their actual political thinking" (Silliman 2007) — the political and environmental activism which drove this collection is recurrent in di Prima's oeuvre. As a matter of fact, di Prima revived

7 For instance, in "Goodbye Nkrumah" di Prima jokes with the use of such revolutionary texts: "a few of us tried it, we tried to stop it with printing/we tried to protect you with mimeograph machines/green posters LUMUMBA LIVES flooded Harlem in those days/well, the best thing to do with a mimeograph is to drop it/from a five story window, on the head of a cop" (146).

8 Pen name often used by Emmett Grogan and Billy Murcott. 
the impetus behind the letters in her latest collection, The Poetry Deal (Di Prima 2014). In "Inaugural Address", the piece that keeps record of the speech given on account of being elected San Francisco Poet Laureate, di Prima revisited the prevailing urge to action felt during the writing of Revolutionary Letters:

the possibility of actualizing some of the dreams I'd absorbed from my anarchist grandfather and hung onto ever since-the chance to actually act on what I believed in, to take a shot at creating the world as we dreamed it-made me eager to join these amazing folks: poets, Diggers, Panthers, Zennies, out-riders and rebels of all sorts, in the hope-filled and wild experiment that was bubbling away in this City 1968. (Di Prima 2014, p. 6)

In addition, just as she famously and loudly declared in "Rant", "THE ONLY WAR THAT MATTERS IS THE WAR AGAINST/THE IMAGINATION” (Di Prima [1971] 2007, p. 104), she continued to use poetry to reinvent a livable San Francisco in The Poetry Deal. Enacting a utopian "urban reinhabitation" — to use Buell's wording (Buell 2001, p. 86)—the poet still fathomed through poetry a city close to nature where people can live freely: "City of sunlight bounced off ocean and bay, city of kindness: of people who have time-time to look each other in the eye." (Di Prima 2014, p. 16) Imagining a "better" city, as di Prima does here as well as throughout Revolutionary Letters, more than a mere utopian positioning, can be analyzed as a reinhabitory effort, an effort "to imagine a city/nature as a livable, or at least survivable, habitat." (Buell 2001, p. 125). This reinhabited or reinhabitized city space comes hand in hand with an ecological responsibility put forward once again by poems such as " 350 ", a poem whose title refers to the 350 parts per million carbon dioxide molecules in the atmosphere that sets the "safe" level human beings have long surpassed, and keep surpassing every year. The forty-year span covered by these two collections attests to the continued centrality of an ecological awareness in di Prima's poetry, a position the poet defended through different approaches in other works, such as Loba.

\section{Loba and Nature}

In addition to an open and ever-expanding nature, Diane di Prima's long epic poem Loba (Di Prima 1998) shares with Revolutionary Letters a preoccupation with ecological issues and the preservation of nature. Revisiting specific mythical and mystic narratives through the elusive and shapeshifting she-wolf goddess, di Prima's Loba appears as feminine presence, both nurturing and threatening, as well as contemporary and primitive. With book one-parts one to eight-mostly written in the 1970s, the collection is strongly influenced by Goddess Worshippers' discourse and, as such, often includes the rather problematic connection between women and nature. This move towards a union between femininity and nature is a position which, as Pramod K. Nayar notes, "is complex as a feminist image, because it naturalizes women and feminizes nature" (Nayar 2009, p. 250). Indeed, as Gretchen T. Legler points out, ecofeminists have long established the need to dissolve such connections, arguing that:

constructions of nature as female (as mother/virgin) are essential to the maintenance of this harmful environmental ethic and are essential to the maintenance of hierarchical ways of thinking that justify the oppression of various 'others' in patriarchal culture by ranking them 'closer to nature' or by declaring their practices 'natural' or 'unnatural'. (Legler 1997, p. 228)

Despite this, the woman-nature link is a recurrent trope in ecofeminist texts and discourses "especially", as Greg Garrard notes, in "those promoting 'radical ecofeminism' and goddess worship" (Garrard 2004, p. 24). "Ave", the first poem in Loba, blueprints the collection's concern over women's representability, and introduces the first connections between the goddess and nature. Opening the book with the verse "O lost moon sisters," (3) di Prima invokes a multiple vision of woman shaped by different descriptions that range from mundane, everyday life situations to mystical representations of a female essence represented through nature. Using parallelism and anaphora to create rhythm 
and emphasize a sense of belonging, the poet addresses all women who wander scattered around the world:

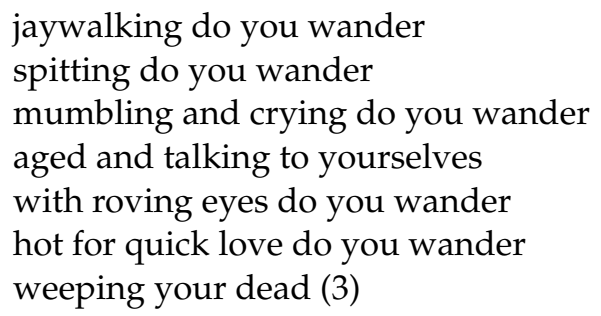

The poet keeps introducing images of women in powerful as well as in powerless positions; women who "tower above [her]" (4) or who "cower on hillsides" (4), and continues to offer multiple examples of female experience-including motherhood, abortion, gender violence, or drug addiction, to name just a few-which are expansive rather than exclusive as far as the definition of woman goes. These rather concrete and situated images, that are generalized but still easy identifiable within a specific socio-political moment, are juxtaposed with a more elusive and mystical representation of female consciousness embodied in nature and objects:

you are hills, the shape and color of mesa you are the tent, the lodge of skins, the Hogan the buffalo robes, the quilt the knitted afghan

you are the cauldron and the evening star you rise over the sea, you ride the dark (5)

Together with these verses, the reference in the opening line to a past female community of women in tune with the moon, as well as the last verses in which the poet aligns herself with the same tradition- "I am you/and I must become you/I have been you/and I must become you" (6) - frames Loba within the specific Mother Goddess neopagan revival of the 1970s, and advances the juxtaposition present in the collection between a socio-politically specified, or "in-context", feminism and an essentialist, all-embracing approach that also permeates the poet's representation of nature ${ }^{9}$. As mentioned above, the dichotomy nature versus culture-with the underlying assumption of a feminine nature as subjective, emotional and private, while masculine culture remains objective, rational and public (Nayar 2009, p. 250)—seems a dubious ally to both the feminist or the ecological cause. As Carolyn Merchant notes in The Death of Nature (Merchant 1983), perpetuating the connection between women and nature seems "to cement existing forms of oppression against both women and nature, rather than liberating either" (xvi). This connection is all the more contentious when informed by Travel Writing and (Post) Colonialist discourses, which have identified highly gendered tropes built on this division such as "the monarchof-all-I-survey" scene by which the "[e]xplorer-man paints/possesses newly unveiled landscape-woman" (Pratt 1992, p. 213). However, and even though di Prima makes ample use of this discourse in Loba-something that was rather marginal in Revolutionary Letters - the poems in the epic effectively convey a similarly pressing and situated experience of eco-crisis. Indeed, a close look at the way in which di Prima links the essence of the she-wolf goddess to nature reveals strong connections with definitions of ecofeminism which highlight the political or activist drive behind the establishment of links between the position of women and nature. Rosemary Radford Ruether, for instance, writes that "[e]cofeminism brings together these two explorations of ecology and feminism, in their full, or deep forms, and explores how male domination of women and domination of nature are

9 For a detailed analysis of the various influences di Prima had in Loba and her overall career, see David Calonne's Diane di Prima: Visionary Poetics and the Hidden Religions (Calonne 2019). In this comprehensive study, Calonne examines, among others, spiritual interests ranging from "Buddhism, Hinduism, Native American culture, Gnosticism, Tarot, astrology, and magic" (116), many of which have a direct impact on Loba. 
interconnected, both in cultural ideology and in social structures"10 (Ruether 1992, p. 2). This correlation is clearly established in poems in which the she-wolf goddess uncovers man's exploitation of nature. For instance, in "And will you hunt the Loba?" the speaker deems those who wish to hunt Loba as fools, stating that none of their techniques will work: "lance, spear or arrow, gun or/boomerang/Think you she can be caught/in nets of love" (29). Mixing the human and animal qualities of the shape-shifting goddess, the poet further exposes an androcentric exploitation of woman/nature for man's own benefit or comfort:
Do you hope
to wrap you warm in her pelt
for the coming winter?
Do you dream
to chew shreds of her flesh from inside of her skin
turn inside out her gut, suck juice
from her large, dark liver? Will you make a cap
of her stomach, necklace of her spine? (29)

Through Loba's human and animal qualities, the denunciation of man's abusive and profitable relationship with nature establishes intimate connections between the exploitation of nature and women in androcentric societies. This position is strengthened by many other poems in the collection in which the poet denounces the history of violence against women, such as "Loba, to Apollo, at the Fountain of Healing"- “was I not sold \& sold \& my daughters broken" (147). It is within this context of systematic abuse that the poet uses the linkage between women and nature to provide a means of, if not escape, at least confrontation. Facing the "fools" that wish to exploit her, Loba resorts to the mystical connection with nature to resist patriarchal assaults. Lying "on her back in the sand like a human woman" (29), she soon morphs into her animal side -“Now/she rises, like the sun, she flicks/her tail" (29)—finally disappearing in the "glassy yellow edge/of your horizon ... " (29). At the end of the poem, Loba completes her great escape by appropriating Jesus' words upon seeing Mary Magdalene after his resurrection-“NOLI ME TANGERE" (29). This "Do not touch me" works on different levels; on the one hand, and as Helen McNeil stated, "[t]he Loba merges ancient and contemporary spirits, bringing curative powers to the diseased city, and acclaiming a female sexual potency that resists being demeaned by male aggression." (McNeil 1996, p. 208) On the other hand, and in the context of a collection that also revisits Biblical events through which further abuses to women and nature are exposed, the appropriation of Jesus' words points towards the denunciation of the perpetuation of the violence against women and nature through the Christian discourse ${ }^{11}$.

Seen in this light, Loba provides an answer to Merchant's initial question: "if women overtly identify with nature and both are devalued in modern Western culture, don't such efforts work against women's prospects for their own liberation?" (Merchant 1983, p. vvi) Despite the use of the mystical discourse often linked with essentialism, di Prima's Loba stresses the necessity of turning away from a literal reading of the Goddess, into a metaphorical and psychological position which grant women the power to continually construct themselves. The Goddess, as the woman who seeks her, appears in Loba in a constant state of evolution - "The Memory of far things/is the continuous presence/in which I discover my Self." (241) The capitalization of "Memory" and "Self" highlights the connection between the presence of the female divine and individual female self-discovery, which is an ongoing process in so far as the image of the Goddess keeps revealing itself to women

10 A similar definition is provided by Janis Birkeland, who notes that "[e]cofeminism is a value system, a social movement, and a practice, but it also offers a political analysis that explores the links between androcentrism and environmental destruction" (Birkeland 1993, p. 18).

11 As Lynn White Jr. writes in "Historical Roots of our Ecologic Crisis" (White 1996): “Christianity, in absolute contrast to ancient paganism and Asia's religions (except, perhaps, Zoroastrianism), not only established a dualism of man and nature but also insisted that it is God's will that man exploit nature for his proper ends." (10) 
in different situations- "She does not leave in her going, she arrives/continuously,/no epiphany/only Presence" (242). One way in which di Prima establishes the Goddess's continuous change is by recurring to all-encompassing descriptions in which the Loba has different forms, inhabiting animals and natural elements, but also objects, sounds, abstract feelings, situations, etc. In the first of three consecutive poems describing Loba included in part three, she is "the wind you never leave behind/black cat you killed in empty lot, she is/smell of the summer weeds, the one who lurks/in open childhood closets, she coughs/in the next room, hoots, nests in your hair/she is incubus" (45). The negativity of these descriptions, which portray Loba as a rather threatening presence, is slightly overturned in the following poem, in which she is described through nature and growth: "she is the scrub oak, juniper/on the mesa, she is Joshua tree/in your desert, she grows/in cracks in the pavement/she tastes of sage, tastes bitter/as chaparral" (47). Here, her bitterness is not related to death or insanity as in the last poem, but to her nature-derived properties"she is born in tangled woodlands of kelp" (46). The juxtaposition of such images ultimately allows the poet to provide both women and nature with an empowering discourse based on self-representation; a discourse that even if just fueled by the poet's imagination, allows nature itself to set its boundaries: "I am the cliff where you may not stand/The mountain where you cannot live" (48). Rather than retreating to a utopian, matriarchal world, the exposition of the abuse of women and nature through this discourse acts as a reminder of the need to take action-even if it is just through acts of the imagination-towards the kind of society in which we want to live. Indeed, although di Prima is much less explicit in her call to arms in Loba than in Revolutionary Letters, the way the poet describes women with nature in similarly threatened or endangered positions allows us to highlight both Loba's feminist and eco-concerned raison d'être. As Noël Sturgeon has aptly affirmed, "the effort to make connections between women and nature rather than between feminism and environmentalism as political movements produces a theoretical context in which conceptions of both women and nature are frequently essentialist." (Sturgeon 1997, p. 264) Hence, it is not about the connection between women and nature- between Loba and her natural and animal qualities - but about the feminist and environmentalist mindset that shapes the poet's urgent call for the revolutionary to take action to save the planet, as well as the denunciation of the abuse women and the natural world are systematically subjected to in Western societies.

\section{Waldman and the Eco-Political Stance}

The inherent power Diane di Prima conferred poetry with the lines "THE ONLY WAR THAT MATTERS IS THE WAR AGAINST/THE IMAGINATION" (Di Prima [1971] 2007, p. 104), is shared and actualized in Anne Waldman's body of work. Just like di Prima, Waldman often uses this power to denounce crimes against nature and delineate a green politics. A long-time believer in the energy and potential of words, in the essay "I is another': Dissipative structures" (Fast Speaking Woman), Waldman links the performative nature of poetry with Speech Acts theories of performative utterances (see Austin 1975) to endow poetry with the ability to effect changes in the world:

Through language one is making gestures that ward off death, that honor the earth, that encourage the rain to fall or someone to fall in love with you, to stop the war, to close down Rocky Flats. Language provides access to the poet's ultimate desire and its manifested efficacy. (Waldman 1996, p. 137)

Building from this premise, Waldman develops a poetics heavily influenced by a situated body that participates in different spheres of social and political life. As part of this body poetics, ecological issues often come under the spotlight of her aesthetic stance. As a case in point, in the same collection, the speaker's day dreams in "Millennium sutra" portray a deteriorating world in which politics and ecological collapse go hand in hand,-_"vote apocalyptic/\& you will get your war" (Waldman 1996, p. 124)—and where harm to the ecosystem is the systematic practice of a greedy and materialistic society: "rain forest stripped \& bare/no trove there/but all you could ever need -/a slump, a 
dress, a new life,/tales to be greedy by/is accessed on a/poisoned machine" (125). The trope of society as a "poisoned machine" leads the poet to dystopian representations of the city as a monstrous entity reminiscent of weiss's "webbed" San Francisco. As a case in point, human consciousness and mental activity create a humanoid and menacing city in the poem "Noösphere" (Kill or Cure): "Intoxicated, I could see all the wires in my walls as veins of some maniacal beast that had its network, its tentacles everywhere. I visualized grids of nerves \& muscle \& electricity of my city." (Waldman 1994, p. 231) Much like di Prima did in Revolutionary Letters, the speaker in Waldman's poem is not oblivious to her own accountability for the eco-crisis she denounces. Guilty by participation and association with the Noösphere, the poet discards elegiac and pastoral modes of nature writing arguing, instead, that the knowledgeable poet can no longer turn a blind eye to the pressing ecological problems she has inadvertently brought forth. In this position, the informed poet wonders "[h]ow can we glorify that seemingly gorgeous Rocky Mountain trail close to Colorado's Rocky Flats when you know how the plutonium has leaked into the streams running through it, giving rise to monstrous distortions, cancers of all kinds." (Waldman 1994, p. 232) It is through this well-informed and unambiguous blame-taking that Waldman situates the performative power of poetry as a tool to stir consciousness and mobilize action.

Having acknowledge one's own accountability for the eco-crisis, one of the ways in which Waldman hopes to affect change in the world is by methodically and critically connecting specific ecological issues with war. This move is present in the poem "Science time" (Skin Meat Bones), where the speaker urges the reader-much as di Prima did in her letters-to "help the world, go further/Set back the clock on the USS Pittsburgh, take it apart,/dismantle those warheads, dig up the poison \& deactivate/its hideousness, admit wrongdoing". (Waldman 1985, pp. 78-79) This theme is further and more deeply developed in The Iovis Trilogy (Waldman 2011), Waldman's epic and ambitious poetic study of the connection between masculinity, war and a multi-directed violence that includes violence against nature. In its more than one thousand pages, the poet investigates the power and reach of scope of Jove, the embodiment of the overrule father who serves as a starting point to explore negative and positive masculine influences in her life. Eco-crises are recurrently denounced through various incarnations of Jove, as the "father who is a kind of power god, master of the nuclear heaven or nightmare" (Waldman 2011, p. 197), but also the poet's son, who appears as hope for a new generation led by a greener consciousness. In addition, through the alter ego "Anne-who-grasp-the broom"-a character that is often used to incorporate archival material and personal correspondence to the epic-Waldman further stresses the performative and political stance of poetry, one that allows her to shape the eco-crisis ${ }^{12}$.

\section{Yellow Jumpsuit Activism: Uh Oh Plutonium}

Rather than a utopian turn-as the poet writes she is "not writing the modern arcadia" (Waldman 2011, p. 1007)—Waldman's determination in The Iovis Trilogy to "[k]eep the world safe for poetry (and everything else)" (Waldman 2011, p. 918) includes the direct address and denunciation of ecological problems. Indeed, instead of resorting to utopian or pastoral modes, the connection between the poet's lived experience and the environment is often made through apocalyptic imagery, a discourse which, as Buell noted, "is the single most powerful master metaphor that the contemporary environmental imagination has at its disposal" (Buell 1995, p. 285). This is the case in one of Waldman's first video projects, Uh Oh Plutonium (Waldman 1982), where she explicitly combines her poetry and political activism with the performance and visual properties of the video clip form-an emerging medium at the time. In this video, the poet expands the performative and multimodal

12 In addition to the many appearances of Anne and her broom, the author's son also voices some of the political concerns of his mother, writing, for instance, to President Reagan to praise his effort to "cut down the number of weapons made every year and to ban the use of chemical weapons" (216); or to Skybox International Inc. to complain about their "not biodegradable or recyclable" (255) packaging, offering some alternatives that would be environmentally friendly. 
qualities of her poetry with the use of shamanistic, mantra-like, forms of chanting and incantation $^{13}$.

Clothed in a yellow one-in-all jumpsuit and backed up by synchronized chorus girls, the poet turns into a lead singer as she utilizes the visibility of the commercial pop hit to denounce the radioactive contamination of the Rocky Flats Plant (Boulder, Colorado) ${ }^{14}$. Located just a few miles from the Jack Kerouac School of Disembodied Poetics, which Waldman co-founded with Allen Ginsberg in 1974, the plant was built in the early fifties and started producing parts for nuclear weapons-concretely fission cores-in 1953. A series of accidents, which took place from 1957-1969, together with leakage produced by the normal activity at the plant, caused plutonium and other highly toxic chemical elements to pollute the plant and the surrounding area, extending even to populated areas of Denver. From the very first leakage of plutonium in the 1957 fire, the government issued no radioactivity warning, hiding the environmental hazard people were exposed to. After a second fire in 1969, civilian monitoring teams started to draw attention to the actual levels of radioactive contamination, resulting in an increased public awareness and the first protests and mobilizations to close the plant. Anne Waldman participated actively in the demonstrations together with poets such as Allen Ginsberg and Peter Orlovsky, and has continued protesting and incorporating this eco-crisis in her work over the years. ${ }^{15}$

In the essay "Warring God Charnel Ground (Rocky Flats Chronicles)" (Vow to Poetry), Waldman describes the history of accidents and mismanagement issues at the plant, as well as the different environmental and health problems the plant has caused and will continue to cause. As the poet writes, "[i]t is exceedingly difficult for the human system to flush out plutonium. Half of the original mass will remain in the body a century after its entry. 'We'll all be glowing for a quarter of a million years,' I sang in protest on Rocky Flats premises in 1976." (Waldman 2001, p. 232) In Uh Oh Plutonium Waldman expands the idea of "glowing with radioactivity" to connect the lyrics of the song with the visual effects offered by video technology. Extending the sentence "We'll all be glowing for a quarter of a million years," Waldman composes the video-poem by listing the unnatural, radioactive glow parts of the human anatomy, objects and landscapes have acquired due to the exposition to plutonium ${ }^{16}$. An apocalyptic portrayal of the future, overcome with nuclear waste, helps the poet make visible the rather invisible threat of radioactive contamination. In the poet's dystopian world of environmental disaster, technicolor infuses and distorts everything, reflecting back an image showing "teeth glowing/microfilm glowing/pages of words glowing/underwear glowing," or "nail and knuckles glowing/sore kneecaps glowing/ankles in despair/storm clouds glowing/hair follicles glowing/golden earlobes/the better to hear you with."

As product of the 1980s, Uh Oh Plutonium is heavily influenced by the "toxic consciousness" Cynthia Deitering uses to describe-mostly U.S.-works that "showed an increasing concern with the pervasive problem of toxic waste" (Deitering 1996, p. 196) and which offer "insights into a culture's shifting relation to nature and to the environment at a time when the imminence of ecological collapse was, and is, part of the public mind and of individual imaginations." (Deitering 1996, p. 196) Using poetry to open up this public debate, and accompanying the glowing metaphor of the lyrics, the video shows different frozen images of crowds of people in urban and rural environments, as well as buildings such as the

13 In the introduction to Manatee/Humanity (Waldman 2009) Waldman writes: “This poem takes its initial inspiration from a particular initiation/teaching_or wang (literally 'empowerment') —in the Tibetan Buddhist tradition, with links to a pre-Vedic shamanic ritual, and from an encounter and meditation on the mysterious manatee, the endangered mammal of coastal waters, and the grey wolf, residing particularly in the western United States." (i).

14 The format of the commercial pop hit can also be seen as an ironic parallelism between the cheap commercialization of music and art and the commercialization of nuclear weapons notwithstanding people's safety.

15 Footage of the demonstration, with Waldman and Orlovsky sitting down on the railway tracks to stop shipments to and from the plant, can be seen in the documentary Fried Shoes, Cooked Diamonds (dir. Constanzo Allione, narrated Ginsberg 1979). At the demonstration Ginsberg read his poem "Plutonium Ode" (1978) and Gregory Corso read "Bomb" (1958).

16 The lyrics of "Uh Oh Plutonium" are an extended version of her poem "Plutonium Poem" (Waldman 1978). The video version changes the opening verse "Fuck Plutonium" of the poem for the softer "Junk Plutonium." 
old World Trade Center or the Taj Mahal, and landmark monuments such as The Statue of Liberty or The Great Sphinx of Giza, to name a few, being altered through the special effects of the video technology. Filtered and distorted through blue, green, red, violet and yellow fluorescent color filters, the images change in swift movements keeping up with the paradoxical upbeat pop tempo. Feeding news of nuclear apocalypse to a society through a celebrated product of mass consumption, and much like Deitering's analysis of novels informed by a toxic consciousness, Waldman provides a representation "of a postnatural world, of a culture defined by its waste, and of a nation that has fouled its own nest". (Deitering 1996, p. 202) Much as it happened in di Prima's work, the dystopian or even apocalyptic turn is not gratuitous, but hopes to bring about change in the world. This is all the more present in Waldman's work when seen in relation to the centrality of orality and performance in her poetics. Indeed, as the poet writes in the essay "Fast Speaking Woman and the Dakini Principle", Uh Oh Plutonium originated as a piece meant to be sung or chanted:

since the first publication of 'Fast Speaking Woman,' I've taught classes on shamanic and ethnopoetic literatures at The Naropa Institute, using, among other texts, Jerome Rothenberg's Technicians of the Sacred, as well as Sabina's imaginative chants. The class one year tried out various enactments of words to create a force field of energy for protest demonstrations at Rocky Flats plutonium plant in Boulder. One evolved into an antinuclear work that was subsequently performed as a group piece. (Waldman 1996, p. 41)

This performative energy translates in Uh Oh Plutonium in alliterative rhythms and the repetition of incantatory verses through which the poet/performer is progressively empowered. Towards the end of the video, with the image of the New York skyline as seen from behind a graveyard, the poet stares defiantly into the camera as she approaches it to sing away the links established between economic profit and human and ecological destruction: "I dedicate this day against megadeath/this Pluto's wealth plus Archia rule/this rule of the wealthy/this Plutolotry/this worship of wealth/I spell away". Drawing etymological connections between the radioactive element and the God of wealth and the underworld-word plays being very common in her work - the poet appropriates the shaman or witch position she identifies with in The Iovis Trilogy and other works to cast a spell against the destruction force of those who benefit from the nuclear weapon industry. Hence, the concluding verses, in which the poet's strong, deep voice crescendos a "mega mega mega mega mega mega mega mega death bomb/ENLIGHTEN!", oppose the radioactive glow of plutonium with the metaphorical enlightenment of social and political awareness. Echoing Ginsberg's performative stance in the approach to orality as a weapon to counterattack environmental and social problems, Waldman's Uh Oh Plutonium parallels Ginsberg's "Plutonium Ode":

I call your name with hollow vowels, I psalm your Fate close by, my breath near deathless ever at your side

to Spell your destiny, I set this verse prophetic on your mausoleum walls to seal you up Eternally with Diamond Truth! O

doomed Plutonium. (Ginsberg 2001, p. 311)

Like Ginsberg, Waldman wishes to enhance social critique through the power of poetry. This visionary, incantatory, aesthetics as well as Tibetan Buddhist rituals such as "wang"empowerment-allow Waldman in this and other works such as Manatee/Humanity ${ }^{17}$ (Waldman 2009) to develop a poetic stance intimately linked with an ecological mindset. This move, ultimately, brings to light the poet's own commitment to exposing the eco-crisis through art.

7 Waldman writes in the introduction: "This poem takes its initial inspiration from a particular initiation/teaching-or wang (literally 'empowerment') - in the Tibetan Buddhist tradition, with links to a pre-Vedic shamanic ritual, and from an encounter and meditation on the mysterious manatee, the endangered mammal of coastal waters, and the grey wolf, residing particularly in the western United States." (Waldman 2009, p. i). 


\section{Conclusions}

The work analyzed in this article gives testimony of the centrality of environmental and ecocritical discourses within and around the Beat generation, at the same time that it stresses the need to expand the theoretical lens through which Beat-related poets such as di Prima and Waldman are often framed. An analysis of di Prima's work through amplified lens that reach beyond her position as the quintessential Beat woman opens up new points of entrance into a poetics in which the Beat generation represents, as David Calonne right notes, merely "a subset of a much larger historical movement in which she situates her own work". (3) In this regard, an approach that takes into consideration the poet's life-long study and influence of Buddhism and mystical traditions as well as situated analysis which considers her participation in counter-culture activist groups such as the Diggers, reveals a strong connection with political and ecological concerns which delineate Revolutionary Letters as well as subsequent works. In much the same way, Waldman's ecological concerns in poetry as well as her environmental activism are deeply ingrained in not just her study of Buddhism and shamanistic practices, but also in her continued development of a body poetics profoundly influenced by the performative qualities of language. In this sense, approaching their work through the theoretical context of eco-criticism foregrounds the profound influence discourses beyond the Beat generation had in their work.

In the works studied, Diane di Prima and Anne Waldman use their poetry to bring to light both general ecological concerns and more specific eco-crises that are denounced or condemned through their poetry. Using utopian and dystopian imagery, as well as other discourses such as the toxic or the apocalyptic discourse, they aim at effecting change in the world by placating local and global eco-crises. Such an arduous task, and frequently naive stance, is addressed critically. Diane di Prima, of the two the poet whose aesthetic most frequently tilted towards the idealization of the revolutionary mode, also makes room in Revolutionary Letters to ironically reminisce her mimeographed-activist-pamphlets days - "well, the best thing to do with a mimeograph is to drop it/from a five story window, on the head of a cop" (146). Similarly, Anne Waldman cannot but agree with the critic that in "Fast Speaking Woman' \& The Dakini Principle" affirmed that "[p]oets are hardly shamans" (Waldman 1996, p. 42). Still, and in keeping with Lawrence Buell's defense of ecocritical writing in Writing for an Endangered World (Buell 2001), the poets analyzed in this article also acknowledge poetry's potential as an act of environmental imagination capable of "register[ing] and energiz[ing] engagements with the world" (Buell 2001, p. 2). Much like Buell, Waldman's reply to the understandably skeptic critic underscores the potential of poetry to act as receptacle and disseminator of world-wide concerns, even while not necessarily bringing about immediate or effective change. Be it as it may, Diane di Prima's and Anne Waldman's poetry show how "making themselves available as 'antennae of the race'" poets can, and indeed often do "receive or tap into energy sources we are usually impervious to." (Waldman 1996, p. 42) This stirring of consciousness, amid the still pressing environmental and ecological crisis, is as relevant today as it was three decades ago.

Funding: Funded by the research project “Queer Temporalities" (PCG2018-095393-I00). Main researcher Juan Antonio Suárez Sánchez.

Institutional Review Board Statement: Not applicable.

Informed Consent Statement: Not applicable.

Data Availability Statement: Not applicable.

Conflicts of Interest: The author declares no conflict of interests.

\section{References}

Austin, John Langshaw. 1975. How to Do Things with Words. Oxford: Oxford University Press.

Birkeland, Janis. 1993. Ecofeminism: Linking Theory and Practice. In Ecofeminism: Women, Animals, Nature. Edited by Greta Gaard. Philadelphia: Temple University Press.

Buell, Lawrence. 1995. The Environmental Imagination: Thoreau, Nature Writing and the Formation of American Culture. London: Princeton University Press. 
Buell, Lawrence. 2001. Writing for an Endangered World: Literature, Culture, and Environment in the U.S. and Beyond. London: Belknap Press.

Buell, Lawrence. 2005. The Future of Environmental Criticism: Environmental Crisis and Literary Imagination. Oxford: Blackwell Publishing.

Callenbach, Ernest. 1975. Ecotopia: The Notebooks and Reports of William Nelson. Berkeley: Heyday/Banyan Tree Books.

Calonne, David Stephen. 2019. Diane di Prima: Visionary Poetics and the Hidden Religions. New York: Bloomsbury.

Chen-Hsing Tsai, Robin. 2012. Gary Snyder: Translator and Cultural Mediator Between China and the World. Comparative Literature Studies 49: 596-609.

Deitering, Cynthia. 1996. The Postnatural Novel: Toxic Consciousness in Fiction of the 1980s. In The Ecocriticism Reader: Landmarks in Literary Ecology. Edited by Cheryll Glotfelty and Harold Fromm. Athens and London: The University of Georgia Press, pp. 196-203.

Di Prima, Diane. 2007. Revolutionary Letters. San Francisco: Last Gasp. First published 1971.

Di Prima, Diane. 1998. Loba. New York: Penguin Books.

Di Prima, Diane. 2001. Recollections of My Life as a Woman: The New York Years. New York: Penguin Books.

Di Prima, Diane. 2014. The Poetry Deal. San Francisco: City Lights Publishers.

Encarnación-Pinedo, Estíbaliz. 2016. Utopia in Progress in di Prima's Revolutionary Letters. CLCWeb: Comparative Literature and Culture 18: 1-7. [CrossRef]

Fazzino, Jimmy. 2016. World Beats: Beat Generation Writing and the Worlding of U.S. Literature. Hanover: Dartmouth College Press.

Garrard, Greg. 2004. Ecocriticism. New York: Routledge.

Ginsberg, Allen. 2001. Selected Poems 1947-1995. New York: Harper Collins.

Glotfelty, Cheryll, and Eve Quesnel, eds. 2015. The Biosphere and the Bioregion: Essential Writings of Peter Berg. New York: Routledge.

Grossinger, Richard, ed. 1978. Ecology and Consciousness. Richmond: North Atlantic Books.

Heise, Ursula K. 2008. Sense of Place and Sense of Planet: The Environmental Imagination of the Global. New York: Oxford University Press.

Legler, Gretchen T. 1997. Ecofeminist Literary Criticism. In Ecofeminism: Women, Culture, Nature. Edited by Karen J. Warren. Bloomington and Indianapolis: Indiana University Press, pp. 227-38.

McNeil, Helen. 1996. The Archeology of Gender in the Beat Movement. In The Beat Generation Writers. Edited by A. Robert Lee. London: Pluto Press, pp. 178-99.

Merchant, Carolyn. 1983. The Death of Nature: Women, Ecology, and the Scientific Revolution. San Francisco: Harper \& Row.

Metesky, George [pseud.]. 1966. The Ideology of Failure. Berkeley Barb, November 25, 6.

Murphy, Patrick D. 2017. Complexity Integration, Ecocritical Analysis, and Gary Snyder Studies. ANQ: A Quarterly Journal of Short Articles, Notes and Reviews 30: 93-100. [CrossRef]

Nayar, Pramod K. 2009. Contemporary Literary and Cultural Theory: From Structuralism to Ecocriticism. Delhi: Longman/Pearson Education India.

Pratt, Mary Louise. 1992. Imperial Eyes: Travel Writing and Transculturation. London and New York: Routledge.

Ruether, Rosemary Radford. 1992. Gaia and God: An Ecofeminist Theology of Earth Healing. San Francisco: HarperSanFrancisco.

Silliman, Ron. 2007. Ed Dorn New American Poetry. Silliman's Blog: A Weblog Focused on Contemporary Poetry and Poetics. March 20. Available online: https:/ / ronsilliman.blogspot.com/2007/03/for-reader-of-my-generation-collection.html (accessed on 15 November 2020).

Sturgeon, Noël. 1997. Ecofeminist Natures: Race, Gender, Feminist Theory and Political Action. New York and London: Routledge.

Tovey, Paige. 2013. The Transatlantic Eco-Romanticism of Gary Snyder. New York: Palgrave Macmillan.

Waldman, Anne. 1978. Plutonium Poem. In New Directions 36: An International Anthology of Prose E Poetry. Edited by James Laughlin. New York: New Directions Books, pp. 97-98.

Waldman, Anne. 1982. Uh Oh Plutonium, Hyacinth Girls Music, NYC, Video.

Waldman, Anne. 1985. Skin Meat Bones: Poems. Minneapolis: Coffee House Press.

Waldman, Anne. 1994. Kill or Cure. New York: Penguin.

Waldman, Anne. 1996. Fast Speaking Woman: Chants and Essays. San Francisco: City Lights Books.

Waldman, Anne. 2001. Vow to Poetry: Essays, Interviews \& Manifestos. Minneapolis: Coffee House Press.

Waldman, Anne. 2009. Manatee/Humanity. New York: Penguin.

Waldman, Anne. 2011. The Iovis Trilogy: Colors in the Mechanism of Concealment. Minneapolis: Coffee House Press.

Weidner, Chad. 2016. The Green Ghost: William Burroughs and the Ecological Mind. Carbondale: Southern Illinois University Press. weiss, ruth. 1958. STEPS. San Francisco: Ellis Press.

White, Lynn, Jr. 1996. The Historical Roots of Our Ecologic Crisis. In The Ecocriticism Reader: Landmarks in Literary Ecology. Edited by Cheryll Glotfelty and Harold Fromm. Athens and London: The University of Georgia Press, pp. 3-14. 